\title{
on the Non-employment Duration of Married Women In Indonesia
}

\author{
Dewi Rochani \\ Master Program in Economics of Population and \\ Employment \\ Faculty of Economics and Business \\ University Indonesia \\ E-mail: dewirochani01@gmail.com
}

\begin{abstract}
Researches in developed countries, especially in western countries, explained the dynamics of women labor supply during life cycle indicated by exit and re-entry in the workforce. The participation rate of female labor force to return to employment is lower when women are in the early years of childbirth and is higher when the children have grown. In the last decade, although the national female Labor Force Participation Rate (LFPR) in Indonesia was still lower than that of male, it showed an increase, from 48.08 percent in 2006 , rising to 50.77 percent in 2016. Interestingly, the peak of women's LFPR is in the 40-44 age group (62.28 percent) or higher than the youth group of 20-24 years old (53.82 percent) which is the prime age group to enter the workforce. Despite the lack of research on women re-entering to the labor market, it can be expected that women in Indonesia may have a high probability of returning to work after childbirth.
\end{abstract}

This study is aimed to find the effects of children age on the unemployment duration of married women to enter labor market by using survival analysis method. The set of covariates used the age of the youngest children, number of children, the age of women, educational attainment, and residence. Based on the data of Indonesia Family Life Survey (IFLS) in 2007 and 2014, it showed that the age of the youngest children has a significant association with the duration of non-employment of married women in Indonesia. Furthermore, the age of women and educational attainment also showed a significant relationship, while number of children and residential area did not show any significant relationship with hazard rate to work.

Keywords-age children, ifls, non-employment duration, married women's employment

\section{INTRODUCTION (HEADING 1)}

In economic theory regarding the allocation of time [1] stated that women would prefer to reduce their supply of labor when they want more time to take care of housework or children. Furthermore, in [2] suggested that the supply of female labor depends on the division of labor within the household. This theory suggests that women traditionally have higher productivity in domestic work related to biological roles in childbearing and child-rearing. This further increased the time value of women to do household than to actively work in the labor market. As long as their home productivity is higher than their wage level, women will allocate most or complete time to do domestic work rather than working in the labor market.

The phases of marriage, childbirth, and the presence of preschool children may reduce the women participation in labor force. Women who have preschool-children tend to lower the probability to return to work [6]. However, the effects of the children age on the women's exiting the workforce weakens the whole life cycle of women as the children grow and no longer require much time to care of them.

Meanwhile, in Indonesia, women's deciding to work is not only related to the individuals' decisions to contribute in the workforce, but also related to the principles of gender, religion, and society's view.. As a country embracing the eastern culture, Indonesia still views the inherent gender role, where there is a division of tasks between men and women. The major societies consider that the main task of men or husbands is to earn a living, whereas women or wives is educating children and performing household [7]

This also creates gender inequalities in employment which is reflected in wages. The report of Development Economics and Sustainability (CDES) in 2015 showed a significant wage discrimination against women in Indonesia. The average gap of basic wage reached $41 \%$ and only a small portion of the gender wage gap could be explained by the productivity differences. This applied both in the formal and informal sectors. One characteristic that could explain is the differences in working experience between men and women in which women have less experience than men because of the interruptions associated with child-rearing.

However, the globalization era has changed the role of women who no longer serve only as a reproduction function 
but also play to increase the economy and welfare of the family.. This is reflected in the increased level of women participation in the labor market in Indonesia over the past decade, although it was still lower compared to the men labor participation rate. Based on National Labor Force Survey (NLFS) in Indonesia, female labor force participation rate increased from 48.08 percent (2006) to 50.77 percent (2016). Even though the men labor force participation rate was higher than women, it decreased in the same period, from 84.22 percent dropped to 81.97 percent. It also showed that women achieved labor force participation rate less than two-thirds of men.

\section{ANALYTICAL FRAMEWORK}

From the discussion above, it is necessary to take the dynamics of women's participation into the research; so that the labor market can obtain not only static variables such as the level of employment and unemployment. It can show the changes of exit and entry in the labor market, as well as factors affecting it.

As [13] who conducted a research in developing countries defined 'broader unemployment'; then the term of unemployment used in this research is defined as a nonemployment that is a condition in which a person is not in a working state. It can be included as a labor force (unemployed), or not as a labor force (such as a retired, or in school, or taking care of a household).

The duration of non-employment indicates a certain period of time for the person who remains in unemployment or not in employment. The duration of non-employment in the labor market is important to explain how employment opportunities should be built and job creation should be made to absorb those included in the unemployment and outside the labor force. Researches on the dynamics of women employment in Indonesia suggested flexible employment creation for women related to their life cycle; especially during pregnancy and raising children. So that women remain active in the job market and can improve their roles in the family's economy [11].

This is because women have a fluctuated working pattern during their life cycle. The responsibilities of rearing the children and taking care of the household lead the transition of women labor participation enter and exit the labor market more often than men.

Some studies in Western countries proved that marital status and childbirth affect the continuity of a woman's working [13]. Unmarried women who had worked normally would leave the labor market at the time of marriage or childbirth and then re-enter the labor market when the child reached school age.

Research conducted by [6] indicates that the participation of working women who have preschool-aged children (less than 6 years) is lower than those who have children at school age (6-18 years). Having preschool-children increases women's chances to exit the workforce, while this probability highly reduces in women who have school-age children..

The previous study done by [9] delivered an opposite result to [6] stating that the duration of the non-employment on women with children age 3 months is faster than women with children aged 2 years. This is because in three months after giving the birth, the productivity value of taking care of children at home approached the wages in the job market; so that many women return to work during this period. It is also supported by the relatively small financial marginal benefit due to bigger child care tax causing large numbers of women return to work. While women with two years old children postpone the non-employment duration to return working because of the high value of leisure to stay at home, other sources of income, or because of the very low market wage offered.

It has been mentioned earlier that the women's decisions to work are related to the time allocation between household production such as taking care of the child or working. Explicitly this is related to the cost of childcare, as well as the availability of childcare facilities, either formally (daycare) or informally by the presence of members of the family or relatives (siblings, aunts, grandmothers) [10].

Some studies suggested that the cost of childcare depends on the children age. The costs applied to infant care of one year old babies would be different to children under two-years old, or caregiving for five-year old children. Institutions serving under-one-year old children are more available than daycares for older children which are usually more expensive since one caregiver can handle less children. [10].

Therefore, this study argues that the process of married women's deciding to actively participate in the labor market depends on the age of the children. This study aims to determine whether there is a relation between the children's age and the non-employment duration of married women in Indonesia. In addition, the study examines the demographic and socio-economic factors covering age, number of children, education, and residential areas that are indicated to affect the duration of non-employment of married women in Indonesia.

\section{METHOD}

The data used in this research are the data of Indonesian Family Life Survey (IFLS) 2007-2014. The initial time defined in this study began in 2007, during the period of working history from 2007 to 2014, where all individuals were at non-employment status in 2007. Thus the unit observation used included married women aged 15 and over with nonemployment status in 2007 with no children, and restricted those with children between ages 0-17 years.

Hazard to work is needed to see a person's probability to work. The hazard to work function in this study used discrete time between years. The duration of non-employment is calculated as the year a person has a non-employment status until the individual year begins to work. Duration of nonemployment is a recurring event in an individual. The duration of the initial observation period of an individual experiencing the event under investigation is called an episode (spell). The non-employment duration in this study was calculated as the year of a person's non-employment status in 2007 until the person started working for the first time to work, is called the first episode of a non-employment event. The second nonemployment duration until it gets to work for a second time is called the second episode and so on. By using hazard function 
can be known how many opportunities to work on the duration of non-employment time is 1 year, 2 years, and so on.

This study uses the left sensor by defining the initial time of observation, at which time all individuals have not experienced the targeted event. The categorical variables of time-varying were work status (whether a woman work or not), the age of the youngest child, the number of children, the age of women and also the educational level (no schooling or elementary as low level; junior secondary, senior secondary as middle level; and tertiary as high level). While variable resident area is time invariant.

Survival analysis was used in this research due to the research objectives that aim to know whether an event will occur and when it will occur. [12]. This method produces both the survival function and the hazard function. The survival function indicates an individual's probability in surviving longer than a certain time. The mathematical formula for survival probability is as follows:

$$
S\left(t_{i j}\right)=\operatorname{Pr}\left(T_{i}>t_{j}\right)
$$

Estimated survival probability value is as follows:

$$
\hat{S}\left(t_{j}\right)=\hat{S}\left(t_{j-1}\right)\left[1-\hat{h}\left(t_{j}\right)\right.
$$

The hazard function provides an overview of the probability to experience an event in short intervals. In a mathematical formula, hazard functions can be expressed as follows [12]:

$$
h\left(t_{i j}\right)=\operatorname{Pr}\left[T_{i}=j \mid T_{i} \geq j\right]
$$

Where $h\left(t_{i j}\right)$ is a hazard function. $\operatorname{Pr}\left[T_{i}=j \mid T_{i} \geq j\right]$ is the first individual probability experiencing an event on condition that the individual has never experienced the incident before. The hazard function can be estimated at each observation time through the following formula:

$$
\hat{h}\left(t_{j}\right)=\frac{\text { event }_{j}}{n \text { exposed }_{j}}
$$

Where $\hat{h}\left(t_{j}\right)$ is the estimated hazard at time j. $n$ event ${ }_{j}$ is the number of individuals experiencing events at time $\mathrm{j}$. $n$ exposed is the number of individuals exposed to time $\mathrm{j}$.

To find out the relationship between age of the child as explanatory variables and non-employment duration as the dependent response and other demographic and socioeconomic factors as control variables, it can be analyzed by discreet time hazard model. The discreet time hazard model is a nonparametric analysis method used to look at the relationship between various variables with the hazard function of an event. Further hazard functions are estimated using logit regression with the following functions hazards models [4]. The log discreet time hazard model can be written as:

$$
\log h\left(t_{i j}\right)=\alpha_{J} D_{J i j}(t)+\beta_{p} X_{p i j}
$$

Where $\alpha_{J}$ is the coefficient of time influence. $D_{J i j}$ is dummy of time, $\beta_{p}$ is the coefficient of influence of explanatory variables, and $X_{p i j}$ is an explanatory variable. For $\mathrm{i}$ is the unit observation and $\mathrm{x}$ is the age of the child as main independent variable and other explanatory variables (covariates).

While the average duration of the non-employment calculated with the formula as follows:

$=\frac{\text { the number of person's years in nonemployment status }}{\text { number }}$ number of people

\section{RESULT}

This study is aimed to find out whether there is a relationship between individual characteristics, household, area of residence, and duration of non-employment. The samples included 1.736 individuals who were at least 15 years old by the year of 2007; and were obtained retrospectively from IFLS 2014. Table 1 shows that non-employment married women are predominantly having under 5 years old (pre-school age) children with a percentage of 68.61 percent; and those having children at the older age group are fewer. It can be said that some of them have more value not to be involved in the labor market. It is also reflected in the average of non-employment duration of married women who have preschool-aged children with longer average of non-employment duration compare to those who have no children and school-aged children. While based on women age group, the largest percentage of nonemployment status in 2007 is in the 25-34 age group; it is related to [6] stating that the prominent characteristic of this group of women is in the fertile period and in the prolonged childcare stage; so that women have a low labor supply. It is also indicated by the longest average of non-employment duration in women groups aged 25-34 than other age groups, with the average of non-employment duration for 4.17 years. Meanwhile, based on the educational level, the lower education group dominates married women with non-employment status with a percentage of 66.42 percent. The results also show that

\begin{tabular}{|c|c|c|c|}
\hline Characteristics of Variables & Number & Percentage & $\begin{array}{c}\text { Average of } \\
\text { Non- } \\
\text { Employment } \\
\text { Duration }\end{array}$ \\
\hline $\begin{array}{l}\text { Number of observat } \\
\text { ion }\end{array}$ & 1736 & 100.00 & - \\
\hline \multicolumn{4}{|l|}{ Age Group of Children } \\
\hline No children & 194 & 11.18 & 2.07 \\
\hline $0-5$ & 1191 & 68.61 & 4.17 \\
\hline 6 and over & 351 & 20.22 & 3.32 \\
\hline \multicolumn{4}{|l|}{ Number of Children } \\
\hline $0-2$ & 1347 & 77.59 & 4.91 \\
\hline 3 and over & 389 & 22.41 & 4.83 \\
\hline \multicolumn{4}{|l|}{ Age Group of Women } \\
\hline $15-24$ & 443 & 25.52 & 2.67 \\
\hline $25-34$ & 904 & 52.07 & 4.14 \\
\hline $35-44$ & 328 & 18.89 & 3.86 \\
\hline
\end{tabular}
the percentage of those with non-employment status is more in urban than in rural area.

TABLE I. UNIT OF ANALYSIS BY CHARACTERISTICS OF VARIABLES AT THE BEGINNING PERIOD (2007) 


\begin{tabular}{|l|r|r|c|}
\hline Characteristics of Variables & Number & Percentage & $\begin{array}{c}\text { Average of } \\
\text { Non- } \\
\text { Eployment } \\
\text { Duration }\end{array}$ \\
\hline $45-54$ & 59 & 3.40 & 3.46 \\
\hline 55 and over & 2 & 0.12 & 2.36 \\
\hline Level of Education & & & \\
\hline Low & 1153 & 66.42 & 5.33 \\
\hline Middle & 501 & 28.86 & 5.33 \\
\hline High & 82 & 4.72 & 5.27 \\
\hline Area of Residence & & & \\
\hline Rural & 628 & 36.18 & 5.40 \\
\hline Urban & 1108 & 63.82 & 5.26 \\
\hline
\end{tabular}

As an illustration, the average of married woman who had no child took a shorter time to return working, for about 2 years; while the average of married woman who had children at pre-school age took almost as long as 4 years to return working. In addition, the average time required for married women who had school-aged children to return working is also 3 years. The survival function shows that married women who had preschool-aged children are steeper than those having school-aged children. This shows that non-employment married women having preschool-aged children returned working sooner than those having school-aged children. This can be assured with the survival probability in the second year approximately 75.47 percent and 77.32 percent for those having preschool-aged children and school-aged children respectively. While in the sixth year of the observation period, it shows that the probability of remaining non-employment status of married women with no children was closely to 10 percent, whereas in groups of women married with children, this condition was achieved in the eight year of observation period.

Furthermore, the survival curve of the duration of nonemployment as seen in Fig. 1. shows that at the beginning of the observation period, the probability to remain in nonemployment status for married women as the unit analysis in this study was still high, and was declining by time. In the first year period, less than 20 percent of non-employment married women were working. While in the second year of research period, the survival probability was 75.29 percent with the value of the 95 percent confidence interval was 0.73 to 0.77 . Meanwhile, the median of non-employment survival time which means that 50 percent of married women in this unit analysis took about 4 years to work. Moreover, in the sixth year, married women remaining in non-employment status reached 20 percent.

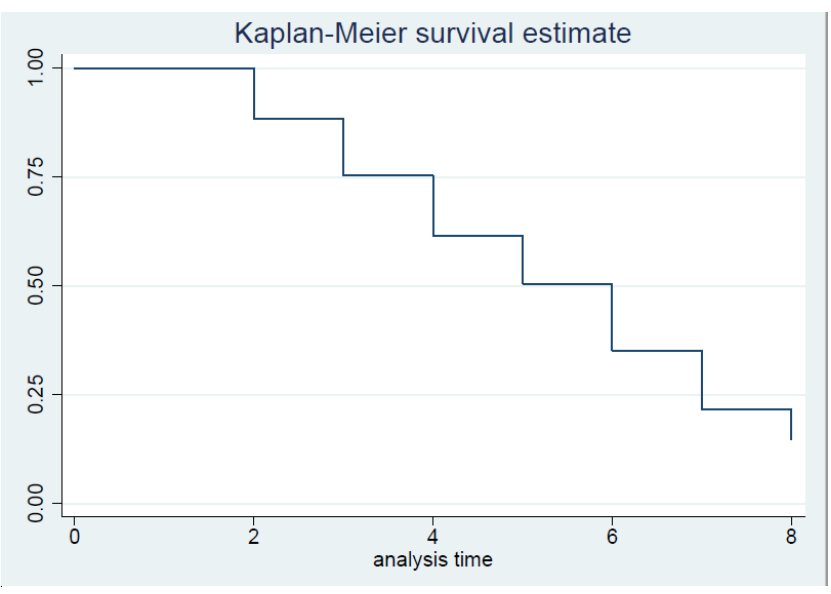

Fig. 1. Survival Plot on Nonemployment Duration

In the meantime, to see if the survival function is the same for the age group of children, Fig 2. shows the differences between married women who have no children, have preschool age children (0-5 years), and school-aged children (6 years and above). It indicates that married women who had preschool-aged children required a longer time for nonemployment duration than those with no children and schoolaged children.

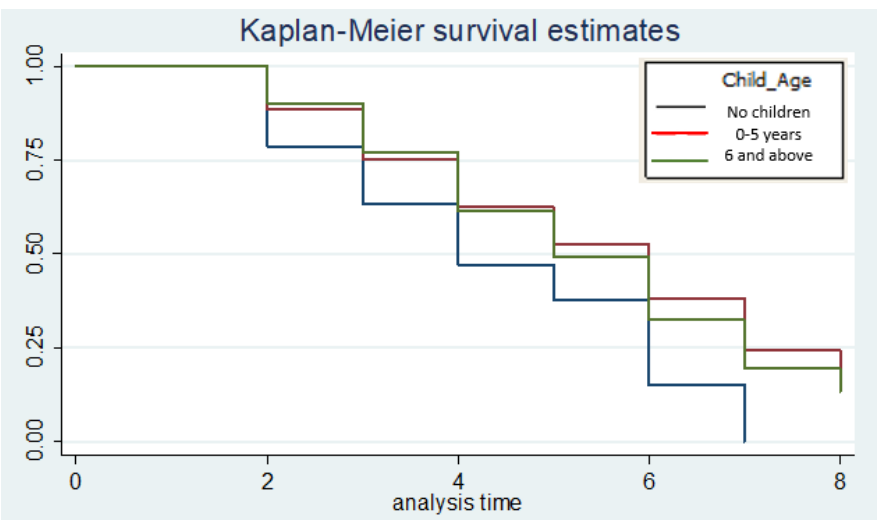

Fig. 2. Survival Plot of Nonemployment Duration at Different Ages of Children

The hazard rate indicates the probability of leaving the non-employment status to get work. Afterwards, discreet time hazard model provides more information on the effects of the youngest child's age towards the non-employment duration of married women. However, this study shows a significant influence where there are differences in the non-employment duration between categories of the youngest children's age and the characteristics of married women.

TABLE II. HAZARD RATIO TO WORK ON MARRIED WOMEN (PERIOD 2007-2014)

\begin{tabular}{|l|c|c|c|c|}
\hline \multirow{2}{*}{ Covariates } & \multicolumn{2}{c|}{ Model 1 } & \multicolumn{2}{c|}{ Model 2 } \\
\cline { 2 - 5 } & $\begin{array}{c}\text { Ratio } \\
\text { Hazard }\end{array}$ & $\begin{array}{c}\text { Standard } \\
\text { Error }\end{array}$ & $\begin{array}{c}\text { Ratio } \\
\text { Hazard }\end{array}$ & $\begin{array}{c}\text { Standard } \\
\text { Error }\end{array}$ \\
\hline $\begin{array}{l}\text { Age Group of } \\
\text { Children (ref. no } \\
\text { child) }\end{array}$ & & & & \\
\hline $0-5$ & $-0.826 * * *$ & 0.199 & $-0.767 * * *$ & 0.203 \\
\hline 6 years and above & $-0.663 * * *$ & 0.203 & $-0.597 * * *$ & 0.209 \\
\hline Number of Children & & & -0.078 & 0.077 \\
\hline
\end{tabular}




\begin{tabular}{|l|l|l|l|l|}
\hline \multicolumn{1}{|c|}{ Covariates } & \multicolumn{2}{c|}{ Model 1 } & \multicolumn{2}{c|}{ Model 2 } \\
\hline $\begin{array}{l}\text { Age Group of } \\
\text { Women (ref. 15-24) }\end{array}$ & & & & \\
\hline $25-34$ & & & $-0.267^{* * *}$ & 0.104 \\
\hline $35-44$ & & & $-0.204 *$ & 0.124 \\
\hline $45-54$ & & & -0.162 & 0.162 \\
\hline 55 years and above & & & 0.251 & 0.482 \\
\hline $\begin{array}{l}\text { Level of Education } \\
\text { (ref. Low) }\end{array}$ & & & & \\
\hline Middle & & & $0.239^{* * *}$ & 0.077 \\
\hline High & & & 0.197 & 0.166 \\
\hline $\begin{array}{l}\text { Area of Residence } \\
\text { (ref. Urban) }\end{array}$ & & & & \\
\hline Rural & & & 0.108 & 0.070 \\
\hline Source & & & \\
\hline
\end{tabular}

Source: IFLS 2007 and 2014, have been processed

Note: $* \mathrm{p}<0.1, * * \mathrm{p}<0.05, * * * \mathrm{p}<0.01$

Table II shows the result of the first model used to see the association between the child's age and the hazard rate to work. While the second model used to see the association between the age of children and the hazard rate to work that is controlled by all characteristics of individuals, households, and residential areas.

The first model shows a significant association between the child's age and the hazard to employment. This result is in line with the previous study which stated that the age of children has a significant relationship to the hazard to work [6]. The negative sign on this coefficient indicates that the higher the age groups of children, than the lower the probability of married women to work.

Similarly, model 2 also shows a significant relationship between the child's age and the hazard of employment after being controlled by all individual characteristics, household, and residence area. This is in line with some previous researches stating the same result. While the negative sign of the age coefficient on the preschool-aged and school-aged children shows that married women who have the youngest child age in both groups had higher non-employment duration than married women who did not have any children [4], [10]. It also shows that the higher the age groups of children, the lower the probability of married women return to work, or in other words the hazard rates to work for married women who have preschool-aged children are higher than those with school-aged children. This is because women productivity in market production is higher than in household production [1], in addition, as has been pointed out in previous research, the presence of relatives, or the availability of child care institutions allow women more quickly to work [9].

The number of children did not show any significant relationship with the hazard rate of employment. This result is in line with previous research in US [5]; although it shows different results based on German country data where there was a significant effect on the increased participation of women employment as the number of children increased.

In addition, the difference in the hazard to work is also indicated by the age variable of women (mother). There is a significant difference in hazard rate to work between women age groups of 25-34 years, and 35-44 years. Married women in the 25-34 age group has the lowest tendency to work. Thus, married women between 25-34 years and 35-44 years have longer non-employment duration compared to women in the age group of 15-24 years. A negative sign in the age group below 55 years indicates that the higher age group will reduce the probability of working compared to the 15-24 age group. It can be explained based on the theory of human capital which states that the physical condition and productivity of work decreases by age, thus reducing the hazard level of employment in the older age group. In addition, the same results were obtained in previous studies where probability to work tend to decline by age [3], [14].

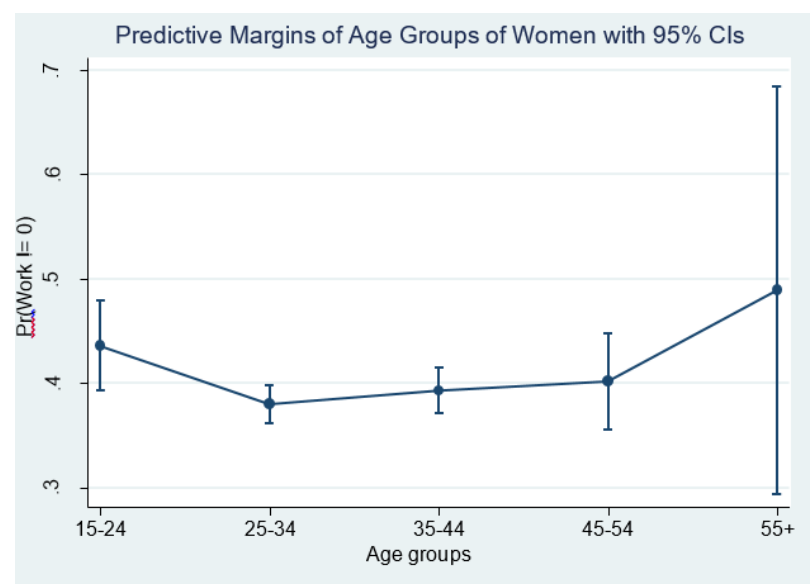

Fig. 3. Predicted Marginal Probabilities of Hazard to Work by Women's Age Groups

Furthermore, as shown in Fig. 3, the predictive margins of probabilities of non-employment exit between women age groups shows that 55 years and over has the largest probabilities to work among other age groups of married women. While the group age of 35-44 and above shows an increasing probabilities to work. It can be said that the higher the age of women, the higher the tendency to work. The results is in line with the hypothesis at the beginning of the study, where the higher the age of women, the shorter the nonemployment duration which is associated to the end of women's fertile period. Eventhough the category of 45-54 and over does not show statistically significant.

Meanwhile, there is positive effect on the employment hazard indicated by individual educational attainment at the middle level of education. Whereas in high level education level did not show significant effect to hazard to work. However, this result is contrary with the previous study which found that the higher the level of education, then the lower the duration of non-employment [14]. 
Residential area variable was also assumed to have an effect on the hazard rate to work [14], but in this study, the status of residential areas statistically did not show any significant relationship with the hazard rate to work.

TABLE III. MARgINAL EFFECT AT MEANS IN MODEL 1 AND 2

\begin{tabular}{|c|c|c|c|c|}
\hline \multirow[b]{2}{*}{ Variables } & \multicolumn{2}{|c|}{ Model 1} & \multicolumn{2}{|c|}{ Model 2} \\
\hline & $\mathrm{dy} / \mathrm{dx}$ & $\begin{array}{c}\text { Standard } \\
\text { Error }\end{array}$ & $\mathrm{dy} / \mathrm{dx}$ & $\begin{array}{c}\text { Standard } \\
\text { Error }\end{array}$ \\
\hline \multicolumn{5}{|l|}{$\begin{array}{l}\text { Age Group of } \\
\text { Children (ref. no } \\
\text { child) }\end{array}$} \\
\hline $0-5$ & $-0.175 * * *$ & 0.042 & $-0.162 * * *$ & 0.043 \\
\hline 6 years and above & $-0.142 * * *$ & 0.043 & $-0.127 * * *$ & 0.044 \\
\hline Number of Children & & & -0.016 & 0.016 \\
\hline \multicolumn{5}{|l|}{$\begin{array}{l}\text { Age Group of } \\
\text { Women (ref. 15-24) }\end{array}$} \\
\hline $25-34$ & & & $-0.055^{*}$ & 0.022 \\
\hline $35-44$ & & & $-0.042 *$ & 0.026 \\
\hline $45-54$ & & & -0.034 & 0.033 \\
\hline $55+$ & & & 0.053 & 0.103 \\
\hline \multicolumn{5}{|l|}{$\begin{array}{l}\text { Level of Education } \\
\text { (ref. Low) }\end{array}$} \\
\hline Middle & & & $0.049 * * *$ & 0.016 \\
\hline High & & & 0.040 & 0.034 \\
\hline \multicolumn{5}{|l|}{$\begin{array}{l}\text { Area of Residence } \\
\text { (ref. Urban) }\end{array}$} \\
\hline Rural & & & 0.022 & 0.014 \\
\hline
\end{tabular}

Source: IFLS 2007 and 2014, have been processed

Meanwhile, the effect of the child's age is also shown by the marginal effect for Model 2 as can be seen in Table III, which shows that the presence of preschool aged children and school-aged children will decrease the probability of working by 16.2 percentage points and 12.7 percentage points compared with those who have no children. While based on the age group of women, it was found that married women belonging to the 25-34 and 35-44 age groups were less likely to work at 5.5 and 4.2 percentage points respectively than those in the younger age group (15-24). In addition, married women with middle education levels will increase the probability to work for 4.90 percent points compared with low education.

\section{CONCLUSION}

This study aims to see whether there is a relationship between the children's age and the non-employment duration of married women in Indonesia. The result of discreet time hazard models showed a significant relationship between the age of children and the non-employment duration. A negative sign was found on the coefficient of preschool-aged and school-aged children indicating that married women who have the youngest child age in both groups had higher nonemployment duration than married women who did not have any children.

This research has limited information on accurate unemployment duration in accordance with the ILO concept, so that the extension of the unemployment concept was done into the non-employment including those who are unemployed, or who are not the labor force. In addition, nonemployment duration information was obtained in units of years; so it is still very rough, because every incident in the employment was treated as the status of work to unemployment. It could occur in a relatively short time, especially on informal jobs. Further research is required to improve the results of this research.

\section{REFERENCES}

[1] Becker, G. S. 1965. Theory of allocation of time. The Economic Journal, 75, 493-517.

[2] Becker, G. S. 1991. Treatise on the Family. Cambridge, MA: Harvard University Press.

[3] Becker, G. S.1965. Investment in human capital: A theoretical analysis. Journal of Political Economy, Vol. 70, No. 5, Part 2: Investment in Human Beings(Oct., 1962), pp. 9-49: The University of Chicago Press.

[4] Blossfeld, H.-P., Golsch, K., and Rohwer, G. 2007. Event history analysis with stata . Lawrence Erlbaum Associates: London.

[5] Drobnič, S., Blossfeld, H.-P., and Rohwer, G. (1999) Dynamics of women's employment patterns over the family life course: a comparison of the United States and Germany. Journal of Marriage and the Family, 61/1, 133-146.

[6] Drobnič, Sonja. 2000. The Effects of Children on Married and Lone Mothers' Employment in the United Statesand (West) Germany. European Sociological Review, Vol. 16, No. 2 (Jun., 2000), pp. 137-157. Published by: Oxford University Press.

[7] Felmlee, D. 1984. A dynamic analysis of women's employment exits. Demography, 21, 171-183.

[8] Ford, Michele \& Parker, Lyn. 2008. Women and Work in Indonesia. New York: Routledge Taylor \& Francis Group

[9] Leibowitz Arleen, Jacob Alex Klerman and Linda J. Waite. 1992. Employment of New Mothers and Child Care Choice: Differences by Children's Age. The Journal of Human Resources, Vol. 27, No. 1, Special Issue on Child Care (Winter, 1992), pp. 112-133. Published by: University of Wisconsin Press.

[10] O'Connell, Martin. 1989. "Maternity Leave Arrangements: 1961-85." In Work and Family Patterns of American Women. U.S. Bureau of the Census, Current Population Reports, Series P-23, No. 165. Washington, D.C.: GPO.

[11] Setyonaluri, D. (2013). Women Interrupted: Determinants of Women's Employment Exit and Return in Indonesia. Bulletin of Indonesian Economic Studies, 50(3), 485-486.

[12] Singer, J. D., \& Willett, J. B. (2003). Applied longitudinal data analysis: Modeling change and event occurrence. Oxford University Press.

[13] Solera, C. 2008. Combining marriage and children with paid work: Changes across cohorts in Italy and Great Britain. Institute for Social and Economic Research (ISER) Working Paper No.2008-22. Essex: University of Essex

[14] Tansel, Aysit, H.Mehmet Tasci. 2004. Determinant of Unemployment Duration for Men and Woman in Turkey. Forschungsinstitut zur Zukunft der Arbeit Institute for the Study of Labor: Germany. 